
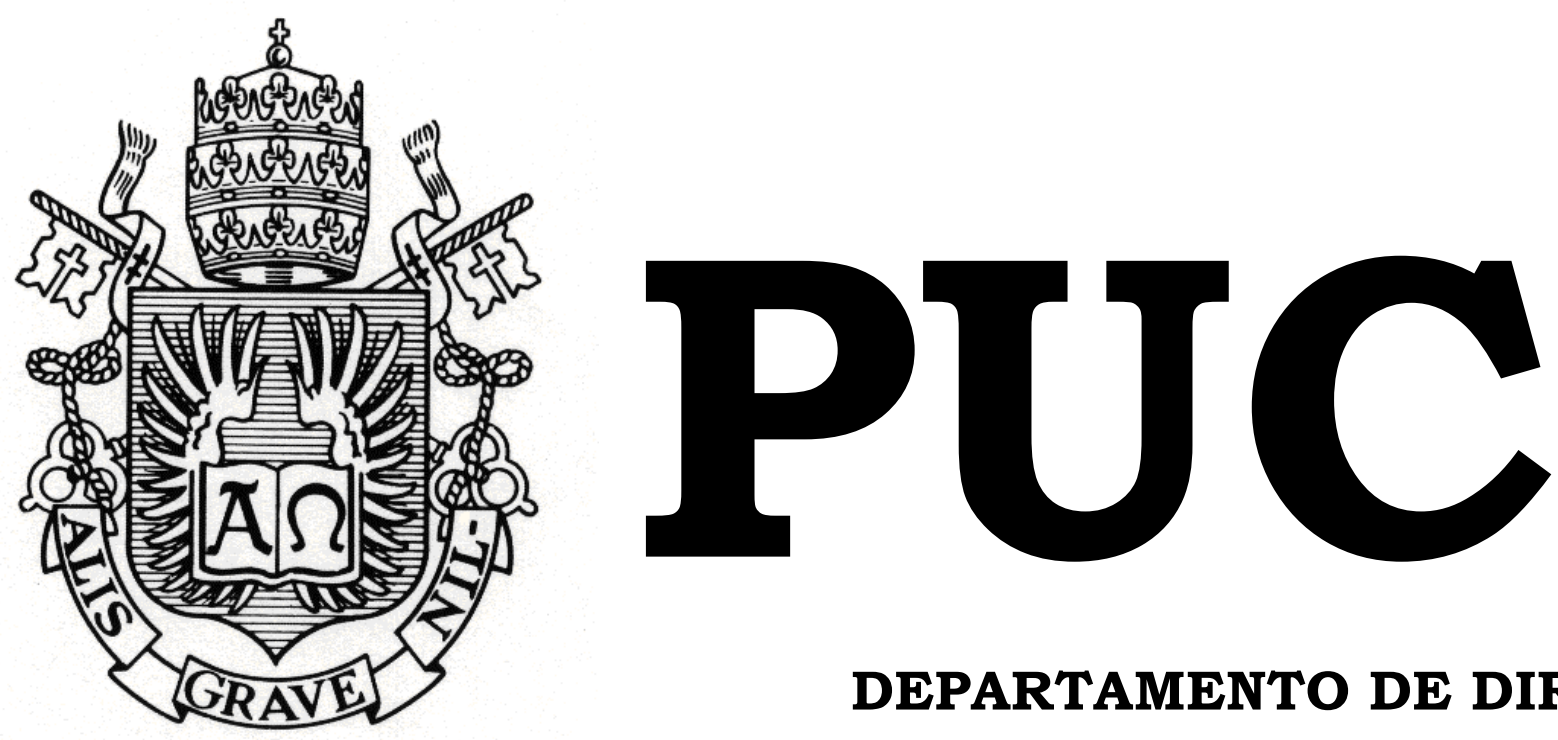

DEPARTAMENTO DE DIREITO

\title{
A inconstitucionalidade da retenção na fonte do imposto de renda no sistema brasileiro
}

\author{
por
}

Gustavo Bustillos Monçores Velloso

ORIENTADOR: Gustavo Junqueira Carneiro Leão

2015.2

PONTIFÍCIA UNIVERSIDADE CATÓLICA DO RIO DE JANEIRO

RUA MARQUÊS DE SÃO VICENTE, 225 - CEP 22453-900

RIO DE JANEIRO - BRASIL 


\title{
A inconstitucionalidade da retenção na fonte do imposto de renda no sistema brasileiro
}

\author{
por
}

\section{Gustavo Bustillos Monçores Velloso}

Monografia apresentada ao Departamento de Direito da Pontifícia Universidade Católica do Rio de Janeiro (PUC-Rio) para a obtenção do Título de Bacharel em Direito.

Orientador: Gustavo Junqueira Carneiro Leão 


\section{DEDICATÓRIA}

Dedico o presente trabalho à minha família, pelo apoio moral e afetivo que me foi dado durante todos esses anos, em especial aos meus pais, à minha irmã e à minha avó. Sem vocês, nada disso teria sido possível. 


\section{AGRADECIMENTO}

Ao meu pai, Roberto Monçores Velloso, responsável pelo ser humano que sou hoje.

À minha mãe, Sonia Del Villar Bustillos Velloso, por todo o incentivo e suporte que me deu ao longo desses anos.

À minha irmã, Roberta Bustillos Monçores Velloso minha companheira de todas as horas nessa vida.

À minha avó, Edith Del Villar Bustillos, por ser o meu porto seguro.

À minha tia, Nanci Monçores Velloso, por ter me ajudado a dar esses passos em uma das fases mais importantes da minha vida, a faculdade. 


\section{RESUMO}

O presente trabalho visa demonstrar como a retenção na fonte do imposto de renda é inconstitucional. Será analisado então o surgimento e desenvolvimento do imposto de renda no Brasil e em outros países, os "critérios" informadores do imposto de renda serão abordados também e, por último, a definição de normas jurídicas, princípios e regras, para concluir pela inobservância do instituto da retenção da fonte do imposto de renda quanto aos critérios da progressividade, universalidade $\mathrm{e}$ generalidade, entendidos como princípios, concluindo então pela consequente inconstitucionalidade.

\section{PALAVRAS-CHAVE}

1. Direito Tributário; 2. Imposto de renda retido na fonte; 3. Critérios; 4. Normas; 5. Princípios; 6. Inconstiucionalidade. 


\section{SUMÁRIO}

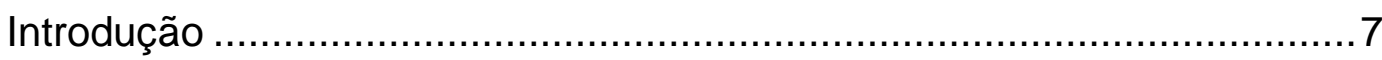

Capítulo 1. O Surgimento do imposto de renda .......................................

1.1. O surgimento do Imposto de Renda na Inglaterra e a evolução histórica nesse país............................................................................

1.2. O surgimento do imposto de renda na Alemanha e a evolução histórica nesse país......................................................................... 14

1.3. O surgimento do imposto de renda no Brasil e a evolução histórica nesse país...................................................................... 17

Capítulo 2. Os critérios da progressividade, universalidade e

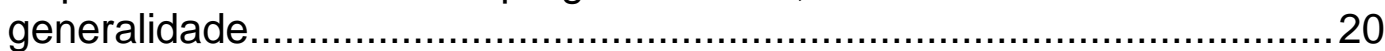

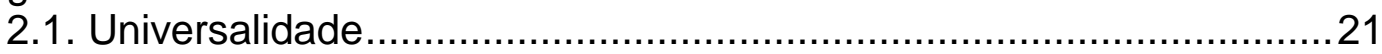

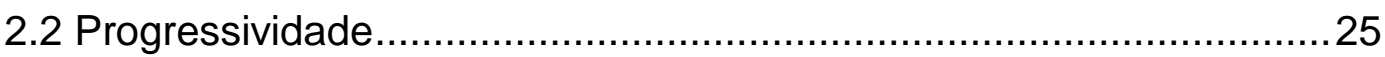

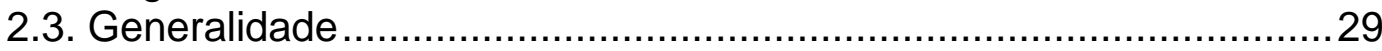

Capítulo 3. A retenção na fonte do imposto de renda brasileiro .................31

3.1. Histórico da retenção na fonte do imposto de renda na Inglaterra ....31

3.2. Histórico da retenção na fonte do imposto de renda no Brasil ...........32

3.3. Retenção na fonte do imposto de renda no modelo brasileiro ...........33

Capítulo 4. Inconstitucionalidade da retenção na fonte por violação

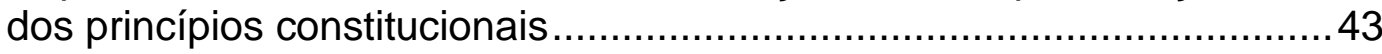

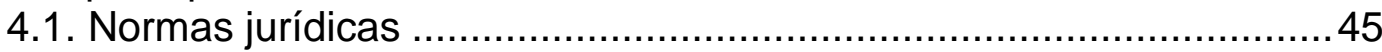

4.2. Inobservância, pela retenção na fonte do imposto de renda, dos princípios informadores da Constituição Federal ..................................50

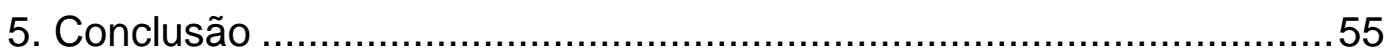

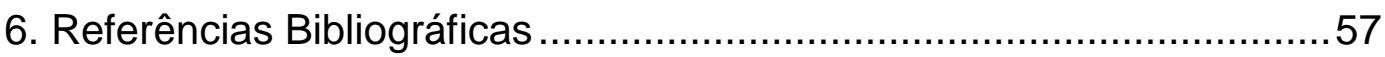




\title{
ABREVIAÇÕES
}

\author{
ART- Artigo \\ CC- Código Civil \\ CF- Constituição Federal \\ CTN- Código Tributário Nacional \\ IRPF- Imposto sobre a Renda da Pessoa Física \\ IRRF- Imposto sobre a Renda Retido na Fonte
}




\section{Introdução}

O presente trabalho acadêmico de conclusão de curso e obtenção do bacharelado em Direito tem por objeto o estudo sobre a inconstitucionalidade da retenção na fonte do imposto de renda no sistema brasileiro.

Apesar do art. 153, III e $2^{\circ}, \mathrm{I}, \mathrm{CF}$ alegar expressamente que o imposto de renda será informado pelos critérios da generalidade, da universalidade e da progressividade, observa-se que os mesmos não são observados pela legislação desses imposto, em especial a que regula a retenção na fonte.

A inobservância dos critérios supracitados pela legislação infraconstitucional importa na sua inconstitucionalidade caso não revertam essa situação.

Para dar maior embasamento ao referido entendimento, o presente trabalho abordará, inicialmente, o surgimento do imposto do renda na Inglaterra, pioneiro na sua instituição, sendo analisado também a criação do mesmo na Alemanha e, posteriormente, no Brasil. Após essa abordagem, a criação do instituto da retenção na fonte desse imposto será objeto de análise.

Em um segundo momento, será explicado o atual funcionamento da retenção na fonte do imposto de renda no modelo brasileiro, sendo analisados os eventos ensejadores da sua cobrança.

Posteriormente, serão analisados os critérios da generalidade, universalidade e progressividade, presentes no art. 153 , III e $2^{\circ}$, I da Constituição Federal, sendo, consequentemente, de observância obrigatória por toda a legislação infraconstitucional que envolva o imposto de renda.

Adquirida essa base teórica, o trabalho passará a abordar a conceituação de princípios, diferenciando-os das regras, com o intuito de 
demonstrar que os referidos critérios tratam-se, na verdade, de princípios, o que agrava o fato da sua inobservância.

Por último, será demonstrado como o instituto da retenção na fonte do imposto de renda não está de acordo com os critérios constitucionais, os quais devem ser entendidos como princípios. Posto isso, será defendida então a inconstitucionalidade do imposto de renda retido na fonte sobre esse fundamento, razão pela qual não deve ser adaptado, ou seja, modificado, para poder continuar em vigor. 


\section{Capítulo 1. O Surgimento do imposto de renda}

\subsection{O surgimento do Imposto de Renda na Inglaterra e a evolução histórica nesse país}

Uma análise histórica nos mostra que o Imposto de Renda surgiu na Inglaterra em meados do século XVIII.

Desde 1793, a Inglaterra estava em guerra contra a França, na época das denominadas guerras napoleônicas. Ameaçado então por um inimigo externo, houve uma defesa notável das posições hegemônicas inglesas no mundo, o que foi possível graças a uma política tributária agressiva.

O Império francês estava em expansão nessa época, dominando um número expressivo de territórios no seu contorno. Em razão disso, a Inglaterra passou por um intenso isolamento política internacional, eis que resistia bravamente contra a expansão francesa.

Porém a Inglaterra possuía dificuldades em conseguir recursos para manter a sua armada, ou seja, para financiar a guerra. Isso foi o fator determinante para que William Pitt propusesse o chamado Triple Assessment, que foi promulgado em 1798 e cuja incidência era sobre o patrimônio e a renda dos contribuintes.

Uma grande inovação desse tributo foi o fato de incidir sobre a renda. Vale ressaltar que a principal fonte de receita no final do século XVIII provinha do patrimônio, razão pela qual os tributos da época incidiam basicamente sobre o patrimônio e consumo. Posto isso, pode-se dizer que o Triple Assessment mudou o sistema tributário vigente.

Ressalta-se o fato de que, antes de criação desse tributo, esse ministro impôs a tributação sobre cavalos, serviçais homens, até mesmo sobre relógios, o que demonstra que o enfoque da tributação era sobre o patrimônio. Apesar das novas fontes de receita, as despesas só cresciam e a 
dívida pública alcançava um valor suntuoso, motivo pelo qual o sistema tributário focou-se na fonte da qual a renda derivava.

Há quem defenda que imposto de renda é a consequência da evolução da teoria da tributação sobre a propriedade. A criação desse tributo representou a primeira fase dessa transição, pois era dada a opção ao contribuinte de optar entre a tributação sobre a sua renda ou sobre o seu patrimônio.

Porém, o Triple Assessment não logrou êxito, eis que a arrecadação proveniente desse mostrou-se muito abaixo do esperado. Um dos motivos do seu fracasso decorreu da sua voluntariedade, pois os contribuintes declaravam sua renda de forma fraudulenta, ou seja, abaixo do limite de isenção. Diante disso, William Pitt desistiu desse tributo e criou o que alguns consideram como o real primeiro imposto de renda da modernidade em 1799.

Esse novo imposto de renda visou corrigir as falhas do tributo antecedente, adotando-se precauções efetivas contra as fraudes nas declarações dos contribuintes. Um exemplo era que, caso houvesse dúvida do fisco, os contribuintes poderiam ser chamados para fornecer esclarecimentos, mas não de forma compulsória.

A oposição parlamentar ao governo vigente da época denominou, ironicamente, esse novo tributo de imposto da guerra, em razão das circunstâncias fáticas do seu surgimento.

Ocorre que o imposto de renda de Pitt não vigorou por muito tempo e, findo provisoriamente o problema financeiro da guerra contra a França, foi excluído do sistema tributário inglês em 1802.

Em 1803, entretanto, um novo imposto de renda, com tributação de fonte e tabelas de rendimento, foi introduzido na Inglaterra por Henry Addington, o qual foi o sucessor de William Pitt. 
Mesmo tendo sido objeto de posteriores alterações, o imposto de renda vigeu durante todo o período da guerra contra a França, ou seja, de 1793 a 1815. A justificativa para tanto era que os gastos com a defesa só eram possíveis com a arrecadação proveniente do referido tributo.

Um fato interessante é que os tributaristas e financistas da época não davam a devida atenção ao imposto de renda, eis que não conseguiam conceber a sua cobrança em momentos de paz.

O imposto de renda inglês daquele momento era considerado então um imposto de guerra, tese essa reforçada pelo fato de que, durante a trégua da guerra entre Inglaterra e França, esse não foi cobrado pelas autoridades responsáveis.

Uma característica marcante era que o imposto não era cobrado de forma equânime entre todos os contribuintes, de forma que a nobreza pouco era afetada pelo mesmo, em razão das suas baixas alíquotas. Obviamente isso aumentou a indignação da população, o que reduziu a popularidade do tributo.

O término do conflito não trouxe consigo o fim da cobrança do imposto, tendo sido decidido que a sua cobrança iria até a assinatura de um tratado de paz.

Após a grande derrota francesa em Waterloo, a paz era eminente, mas a insegurança referente à cobrança perpetuava-se. Posto isso, uma parcela da população se mostrou contra a reintrodução do imposto no sistema tributário, mas o governo não levou em conta essa reivindicação e, em 1816, o reintroduziu no sistema.

Um fator determinante para o governo ter tomado essa atitude foi o potencial de exação do imposto de renda, após as correições dos seus defeitos. Vale ressaltar que, em 1816, esse imposto respeitava o mínimo existencial, ou seja, até uma renda de 60 libras, o indivíduo não era 
tributado. Outra característica era a de uma alíquota reduzida para os contribuintes que tivessem uma faixa de renda entre 60 e 200 libras.

Inegável a efetividade da arrecadação proveniente da cobrança do imposto de renda, o que, de fato, foi um fator importante para a sua perpetuação no sistema tributário inglês.

Apesar das vantagens auferidas pelo tributo, o mesmo deixou de ser cobrado por um período de 25 anos, voltando a ser introduzido definitivamente em 1842 na Inglaterra, não estando mais vinculado à noção de imposto de guerra, na denominada segunda era do imposto, mas ainda era objeto de contestação por grande parte da população.

Os contribuintes alegavam que o imposto de renda não respeitava a confidencialidade, sendo invasivo, eis que implicava na investigação do seu negócio, o que segundo eles, não deveria estar ao alcance do fisco. A evolução do direito privado contribui para o desenvolvimento dessas ideias.

Vale ressaltar que, desde o momento da instituição do imposto de renda, prevalecia o liberalismo econômico na Inglaterra, cujos expoentes eram: Adam Smith, John Stuart Mill, entre outros. Essa teoria entendia que o Estado não deveria intervir nas relações econômicas entre indivíduos.

O imposto de renda ia contra o ideal pregado pelo Liberalismo, pois, para proceder à arrecadação devida, o Estado muitas vezes intervinha nos negócios celebrados pelos contribuintes, demandando esclarecimentos acerca dos mesmos, exigindo a exposição dos valores pactuados, entre outras medidas. Isso, na visão de muitos, violava a confidencialidade dos negócios, gerando muita revolta.

Adam Smith chegou a alegar que o imposto de renda demandaria uma inquisição mais intolerável do que qualquer tributo além de ser, ao mesmo tempo, tanto arbitrário como incerto. 
Apesar de toda a resistência da população, a qual foi nitidamente influenciada pelos ideais liberais, o imposto de renda prevaleceu na Inglaterra, sendo cobrado normalmente.

Esse modelo de imposto de renda tinha como característica a subdivisão em alíquotas, sendo cada uma aplicável a uma faixa de renda do contribuinte, aproximando-se mais do nosso modelo.

Insta salientar que, desde aquela época, a conceituação de renda era um problema que trazia insegurança e instabilidade jurídica, eis que muito genérica.

Concomitantemente à reintrodução desse tributo, a Inglaterra passava por uma significativa alteração na área da Teoria da Empresa, por meio de leis que traziam alterações consideráveis no tratamento dado às empresas. Isso demonstra que se buscava uma sintonia entre o direito privado e o sistema tributário nacional, visando impedir conflitos futuros.

Apesar de todas as modificações, o Imposto de Renda não agravada em nada a população, sendo alvo de inúmeros embates nas mais diversas áreas.

No parlamento britânico, o ministro das finanças Robert Peel, em 1845, fez uma defesa do Imposto de Renda, argumentando que esse deveria ser cobrado em tempos de paz, pois tinha a capacidade de cobrir o crescente déficit público, o que tornaria desnecessária a criação de outro tributo com essa finalidade.

Outra problemática trazida na época era a conceituação de renda, termo de difícil conceituação que foi considerado como rendimentos pagos pela monarquia pelo uso de propriedades, rendas públicas da própria coroa, lucro das empresas e sociedades de fato, rendimentos do capital de residentes no Reino Unido, rendimentos de qualquer tipo de propriedade, mesmo além do Território britânico. Os rendimentos das pessoas naturais 
também foram considerados renda tributável, estando incluso nesse conceito a renda do trabalho realizado em território britânico. ${ }^{1}$

Uma alteração fundamental no Imposto de Renda decorreu de uma lei de 1850 , segundo a qual bastava que o contribuinte fosse residente no Reino Unido para que fosse sujeito passivo do imposto de renda. Essa mudança auxiliou na captação de riqueza, ainda que não contribuísse para a conceituação do termo renda.

Em 1909, foi introduzida a progressividade em relação ao imposto de renda, devendo ser entendida como uma forma de arrecadação circunstancial rápida. Ressalta-se que, apesar de todas as modificações, o contribuinte não o aceitava, sob a alegação de que possuía um caráter invasivo, eis que "investigava" os seus negócios.

\subsection{O surgimento do imposto de renda na Alemanha e a evolução histórica nesse país}

O desenvolvimento do imposto de Renda no sistema alemão mostrase importante, pois, além das inovações trazidas, influenciou muitos outros modelos. Posto isso, passa-se agora a uma análise do mesmo.

A fama do imposto de renda espalhou-se rapidamente pela Europa após o seu surgimento na Inglaterra. Os alemães, por sua vez, adotaram o novo imposto e o desenvolveram de acordo com as suas particularidades.

Muitos alemães possuíam críticas ao imposto de renda inglês, especialmente por o acharem intrusivo além de ter medidas vexatórias. Entretanto eles, nesse primeiro momento, o aceitaram na perspectiva de ser temporário. Insta salientar que os ideais do liberalismo econômico, encabeçadas por Adam Smith, propagavam-se cada vez mais pela Europa, especialmente a Alemanha, o que os influenciou a ter esse entendimento.

\footnotetext{
${ }^{1}$ GAMMIE, Malcon. The origins of fiscal transparency in uk income tax. In: Tiley, John. Studies in the history of tax law. Volume 4. Oxford and Portland, Oregon: Hart Publishing, 2010, pp 3366.
} 
O primeiro imposto de renda deles foi introduzido em 1808 nas províncias do leste da Prússia e na Lituânia, as quais eram subordinadas à soberania da monarquia prussiana. Esse imposto era baseado na capacidade contributiva do contribuinte, possuindo uma alíquota progressiva.

Apesar da oposição ao imposto, houve quem o defendesse como Von Stein, o qual alegou que o imposto de renda era o imposto mais justo de todos, pois afetava todos os cidadãos e todas as fontes de renda nacional. A referida defesa, aliada ao desastre financeiro vivido na região, acabou por convencer o primeiro ministro prussiano a implantá-lo em toda a Prússia, apesar de todas as hesitações.

O ato de 6 de dezembro de 1811 introduziu de forma temporária o imposto de renda em toda a Prússia enquanto havia a ocupação das tropas francesas em certas áreas.

Por vez, em 1812 apareceu o primeiro e geral imposto sobre a renda e a propriedade na Prússia, possuindo um caráter definitivo e tendo sido concebido como um tributo de guerra, devido aos conflitos contra a França.

O novo imposto preponderava a declaração própria dos contribuintes, de forma que, uma vez feita, as medidas "vexatórias" fiscais seriam evitadas. O fisco, caso tivesse uma grande suspeita, poderia proceder a uma investigação, para melhor apurar as informações fornecidas pelo sujeito passivo.

Após o fim da guerra contra a França, o imposto de renda foi revogado pelo ato de 7 de setembro de 1814 , não se tornando permanente dentre do sistema vigente.

A noção de tributo sobre a guerra contribui muito para isso, pois os cidadãos não conseguiram concebê-lo fora do período conflituoso. Outros fatores que influíram para o seu foram: a grande crise econômica vivida na região em razão da guerra fez com que a alíquota do imposto cobrada fosse tida como muito alta; a administração, responsável pela sua fiscalização e 
cobrança, era muito insatisfatória graças a complexidade do imposto e do grande número de deveres dos fiscais.

$\mathrm{O}$ fracasso desse primeiro modelo geral de imposto de renda teve consequências a longo prazo na Prússia, eis que não foi mais instituído por um longo tempo. Em 1820 um novo tributo foi criado na região, mas tinha poucas semelhanças com o imposto de renda, pois não possuía institutos fiscalizatórias de grande eficácia, classificando então a população em classes de acordo com as suas aparências, ou seja, conforme as riquezas que aparentava ter.

A reintrodução do imposto de renda na Inglaterra em 1842 por Peel motivou que o mesmo ocorre na Prússia. A grande diferença é que, desta vez, o mesmo não tinha caráter permanente, não sendo mais cobrado em razão das guerras.

Uma lei para a reintrodução do imposto de renda foi proposta na Prússia em 1847, indo de encontro a uma grande oposição, o que a impediu de entrar em vigor. A previsão de uma declaração compulsória pelos contribuintes foi o motivo da indignação.

A necessidade de aumento da receita governo culminou com uma reforma em 1851 na administração, a qual culminou na criação de um novo imposto de renda. A grande diferença desse é que não era mais necessária uma declaração compulsória do contribuinte.

Porém a ausência de declarações verídicas aliada à deficiência da administração fez com que o novo imposto não tivesse cumprido as suas expectativas, que eram de uma tributação igual de todos os cidadãos. Posto isso, o governo prussiano procedeu a uma reforma desse em 1869 , sem sucesso, entretanto.

Outra reforma foi feita em 1873, mas não atingiu o objetivo principal, eis que o fisco ainda estava impedido de fazer inquisições acerca dos 
negócios dos contribuintes e, consequentemente, das suas declarações, perpetuando assim o "sistema da mentira e da trapaça".

Em 1891 foi feita uma grande reforma no sistema tributário prussiano, denominada de reforma tributária de Miquel'sche, a qual implicou em mudanças no imposto de renda, fazendo com que esse se tornasse o tributo mais importante da época.

A referida reforma implantou o conceito de fontes de renda, ou seja, essas eram separadas na declaração de acordo com a sua proveniência, o que tornou a avaliação da renda mais acurada e fazendo as auditorias das autoridades fiscais mais eficientes.

Essa reforma de 1891 estabeleceu o caminho para a Alemanha, a qual, após a primeira guerra mundial implantou um imposto de renda para toda a Alemanha, baseando-se no ato de 1891 e tendo como principal alteração a retenção na fonte para algumas rendas específicas.

\subsection{O surgimento do imposto de renda no Brasil e a evolução histórica nesse país}

Há uma divergência na nossa doutrina acerca do nascimento do imposto de renda no Brasil, em razão da dificuldade de se conceituar o termo renda. Duas são as doutrinas sobre o tema.

A primeira corrente doutrinária, a qual aponta os anos de 1808 e 1843 como os de surgimento do imposto de renda, defende que esse imposto deve ser entendido como o incidente sobre apenas uma espécie de rendimento como no caso dos dividendos distribuídos.

A segunda corrente, que aponta o surgimento do imposto de renda no ano de 1924, tendo como base a lei de 1922, defende que, somente nos casos do tributo alcançar os rendimentos globais, englobando todos os 
acréscimos patrimoniais das sociedades ou indivíduos, é que se pode admitir a presença do imposto de renda.

A lei 317 de 1843 possuía, em seu artigo 23, uma disposição que determinava que todas as pessoas que recebiam vencimentos dos Cofres Públicos Gerais, por qualquer título que fosse, ficavam sujeitas a uma imposição, tendo inspirado a primeira corrente doutrinária. $\mathrm{O}$ referido diploma legal previu hipóteses de isenção, excetuando a cobrança desse tributo nos casos de funcionários do Governo que recebessem vencimentos de pouca monta.

Um aspecto interessante a ser ressaltado é que essa lei tinha um prazo determinado de um ano. Nasceu então como um imposto extraordinário, cujo objetivo inicial era financiar as guerras internas que ocorriam no país, em especial a Guerra dos Farrapos, a qual ocorreu no sul do Brasil.

Em 1891, após a proclamação da independência do Brasil, foi promulgada uma nova Constituição Federal. Por vez, esta não previu expressamente o imposto de renda.

Entretanto o artigo 12 dessa Constituição previa a possibilidade de criação de novos impostos, ao determinar que:

\footnotetext{
“Além das fontes da receita discriminadas nos artigos $7^{\circ}$ e $9^{\circ}$, é lícito à União como aos Estados cumulativamente ou não, criar outros quaisquer, não contravindo o disposto nos artigos $7^{\circ}, 9^{\circ}$, e $11^{\circ}, n^{\circ} 1 . "$
}

A única restrição mencionada no artigo supracitado era quanto à instituição de novos tributos, nos casos em que houvesse competência privativa da União ou dos Estados. Portanto estavam livres para instituírem e exigirem o Imposto de Renda a União e os Estados. Vale ressaltar que, naquela época, não existia a figura do Município, razão pela qual não há menção alguma quanto a este.

O termo imposto de renda só veio a aparecer no século XX no nosso ordenamento como rubrica de orçamento. 
Por vez, a lei 4.625/1922 prevê expressamente o imposto de renda ao dispor no art. 31 que:

"Fica instituído o imposto geral sobre a renda, que será devido, anualmente, por toda pessoa física ou jurídica residente no território do país, e incidirá, em cada caso, sobre o conjunto líquido dos rendimentos de qualquer origem".

A referida lei determinou que a sua arrecadação seria efetivada em 1924, mas isso não ocorreu, eis que o decreto baixado em 1924 nunca foi posto em efetiva execução. Isso foi feito pelo Decreto 17.390/1926, o qual regulava a lei 4.984/1925.

Apesar das diversas impugnações, o imposto de renda continuou a ser exigido, sendo incluído no sistema tributário brasileiro e tido, posteriormente, como fonte de receita da União, conforme a Constituição Federal de 1934.

Pode-se perceber então que, apesar de cobrado provisoriamente nos seus primórdios, visando "financiar" um período de guerras internas, o imposto de renda, posteriormente, foi cobrado de forma definitiva, perpetuando-se e tido como fonte de receita da União. Portanto o seu objetivo atual é o de aumentar a arrecadação, o que mostra a sua similitude com o imposto de renda inglês, cujo desenvolvimento, apesar das peculiaridades, ocorreu de forma semelhante. 


\section{Capítulo 2. Os critérios da progressividade, universalidade e generalidade}

A retenção na fonte do imposto de renda é um instituto do imposto de renda, cujo objetivo é tributar acréscimos patrimoniais isolados, sem levar em conta o período-base aplicável às pessoas físicas ou jurídicas, antecipando assim a arrecadação do montante referente a esse tributo.

Por ser um instituto do imposto de renda, a retenção na fonte deve se sujeitar às limitações impostas legal ou constitucionalmente a esse.

Posto isso, deve-se ressaltar que o art. 153, parágrafo $2^{\circ}, \mathrm{I}, \mathrm{CF}$, determina que:

Art. 153. Compete à União instituir impostos sobre:

III - renda e proventos de qualquer natureza;

$\S 2^{\circ} \mathrm{O}$ imposto previsto no inciso III:

I - será informado pelos critérios da generalidade, da universalidade e da progressividade, na forma da lei;

O dispositivo supracitado deixa claro que o imposto de renda deverá ser informado pelos critérios da generalidade, universalidade e progressividade, os quais serão analisados detalhada e individualmente em seguida. A retenção na fonte, por ser um instituto desse imposto, deveria, em tese, obedecê-los também.

O grande problema dessa norma constitucional é que ela é de eficácia limitada, pois determina que, na forma da lei, o imposto de renda será informado por esses critérios. Torna-se necessária então uma norma infraconstitucional regulando a sua aplicabilidade.

Pode-se dizer então que a referida norma é de aplicabilidade mediata e reduzida. O efeito produzido é mínimo, vinculando o legislador infraconstitucional, pois o estabelece um dever além de ter eficácia ab- 
rogativa da legislação incompatível com o ali disposto. (Pedro Lenza, Direito Constitucional, Col. Esquematizado, 2013, pag. 280).

Conforme entendimento do mestre do Largo São Francisco, o art. 153, parágrafo $2^{\circ}, \mathrm{I}, \mathrm{CF}$ é uma norma de eficácia limitada, declaratória de um princípio intuitivo ou organizativo, eis que possui um esquema geral para a estruturação do imposto de renda.

De acordo com a classificação criada por Maria Helena Diniz, essa seria uma norma com eficácia relativa complementável ou dependente de complementação legislativa, já que a sua possibilidade de produzir efeitos é mediata, ou seja, enquanto não for promulgada a lei que a norma faz menção, os seus efeitos positivos não serão produzidos, entretanto terão a eficácia paralisante de efeitos das outras normas incompatíveis com o que preceituam.

Passa-se agora a uma análise mais detalhada dos critérios da universalidade, generalidade e progressividade.

\subsection{Universalidade}

Ricardo Mariz de Oliveira preceitua que:

O princípio da universalidade significa que todo o patrimônio do contribuinte deve ser considerado na sua integralidade, sem qualquer fracionamento, seja no seu marco inicial de comparação (no momento inicial do período de apuração), seja no seu marco final (no momento final do período de apuração), portanto, também quanto às suas mutações ocorridas no período. ${ }^{2}$

O critério da universalidade, como o próprio nome da a entender, determina que todos os fatores positivos e negativos que compõem o patrimônio do contribuinte dentro do período-base assim como os fatores

\footnotetext{
${ }^{2}$ OLIVEIRA, Ricardo Mariz de. Fundamentos do Imposto de Renda. Ed. Quartier Latin. São Paulo. p. 255
} 
que o diminuem ou aumentam sejam levados em conta no momento da apuração do Imposto de Renda.

A consequência principal desse critério é que o imposto de renda passa a ser cobrado em relação a todos os tipos de bens e categorias de pessoas, pressupondo então que, caso os contribuintes se encontrem em uma situação semelhante, devem ser tributados de maneira idêntica, pois, em tese, possuem a mesma riqueza.

Outro ponto a ser observado é que, em razão dessa característica da universalidade, a carga tributária do imposto de renda é dividida pelo maior número de bens possíveis, sendo então mais justa, eis que tributa de forma mais isonômica. ${ }^{3}$

Insta salientar que o termo universalidade patrimonial aqui deve ser entendido conforme o preceituado no art. 91, CC, ou seja, é o complexo de relações jurídicas de uma pessoa, dotadas de valor econômico, ressaltando que, em razão do art. $110 \mathrm{CTN}$, a lei tributária não pode alterar a definição desse instituto típico do direito privado, de forma a limitar ou definir competências tributárias.

Por vez, os fatores de mutação patrimonial não tem como condão a constituição de um novo bem coletivo que seja diferenciado do patrimônio. Posto isso, Ricardo Mariz de Oliveira conclui de forma acertada que:

"Portanto, o princípio da universalidade exige que se tribute todo o aumento patrimonial ocorrido no período previsto em lei, por inteiro e em conjunto, sem fracioná-lo e novamente sem distinguir as espécies de rendas e proventos, ajustando-se, assim, ao princípio da generalidade." ${ }^{4}$

Vale ressaltar que, apesar da observância imposta desse critério, certos acréscimos patrimoniais ainda estarão isentos de tributação, ou seja, não serão considerados fatos geradores do imposto de renda.

\footnotetext{
${ }^{3}$ EMYGDIO, F. da Rosa Jr., Luiz, Manual de Direito Tributário, 2a Ed., Editora Renovar, p. 612.

${ }^{4}$ OLIVEIRA, Ricardo Mariz de. Fundamentos do Imposto de Renda. Ed. Quartier Latin. São Paulo. p. 256
} 
A universalidade a ser observada pelo imposto de renda é um instituto relativamente recente. Até o ano de 1987 entendia-se que os rendimentos auferidos no exterior não estavam sujeitos ao imposto de renda de pessoa jurídica por exemplo, não sendo então tributados.

O Decreto-lei n 2.397 de 1987 previu, pela primeira vez, a possibilidade de tributação dos lucros e rendimentos obtidos fora do Brasil, ao estipular os resultados obtidos no exterior, diretamente ou através de filiais, sucursais, agências ou representações seriam computados no lucro real das pessoas jurídicas.

Entretanto, o Decreto-lei n ${ }^{\circ} 2.429$ de 1988, em seu art. 11, revogou o art. $8^{\circ}$ de outro Decreto-lei, o qual previa a possibilidade dessa tributação universal. Isso impediu que se efetivasse a tributação dos rendimentos auferidos no exterior, não se concretizando o critério da universalidade.

Somente em 1995, com o art. 25 da lei no 9.249, é que passaram a ser tributado os todos os lucros, rendimentos e ganhos de capital auferidos no exterior por pessoas jurídicas domiciliadas no brasil.

Esse artigo faz menção aos rendimentos e ganhos de capital auferidos no exterior por pessoas jurídicas. Pelo fato desses atos serem diretamente realizados por pessoas jurídicas, é que devem ser contabilizados no Brasil, sendo computados na apuração do lucro líquido das pessoas jurídicas.

A outra parte do artigo aborda os lucros auferidos por filiais, sucursais, controladas ou coligadas no exterior, de pessoas jurídicas domiciliadas no Brasil. Aqui, o termo rendimentos não é mais utilizado, falando-se apenas dos lucros. Os lucros serão então computados na apuração do lucro real.

Posto isso, Alcides Jorge da Costa defende que:

"Sem prejuízo da aplicação do método da equivalência, que não conduz à tributação, as pessoas jurídicas devem adicionar ao lucro real, no Lalur e na 
declaração dos rendimentos, os lucros realizados por filiais, sucursais, controladas ou coligadas, quer estas os tenham distribuído, quer não." 5

Deve-se ressaltar que haverá a conversão, em Real, dos lucros, pela taxa de câmbio, para venda, do dia das demonstrações financeiras em que os lucros da filial, sucursal, controlada ou coligada tenham sido apurados. De suma importância também é o fato de que os prejuízos e perdas dessas não podem ser compensados com os lucros auferidos no brasil.

Essa lei, no seu art. 26, prevê que “a pessoa jurídica poderá compensar o imposto de renda incidente, no exterior, sobre os lucros, rendimentos e ganhos de capital computados no lucro real até o limite do imposto de renda incidente, no Brasil, sobre os referidos lucros, rendimentos e ganhos de capital."

Insta salientar que todas as pessoas jurídicas que tiverem lucros, rendimentos ou ganhos de capital auferidos no exterior estão obrigadas ao regime de tributação com base no lucro real, conforme preceituado no art. 26 da lei 9.249/95.

A referida lei permitiu pela primeira vez, salvo algumas exceções, que todos os rendimentos, ganhos de capital e lucros auferidos no exterior fossem tributados pelo fisco brasileiro, concretizando o critério da universalidade do imposto de renda.

Esse fato deixa claro a principal característica do critério da universalidade, o qual é considerar todas as rendas do contribuinte como uma unidade, sem distinções, no momento da declaração do imposto de renda 6 .

Por vez, Renck defende que:

A base calculada, além de ser informada pela generalidade, terá de ter natureza universal. Ser universal é ser total. Logo, de nada adianta apurar a base

\footnotetext{
${ }^{5}$ COSTA, Alcides Jorge da Costa. Imposto de Renda, alterações fundamentais. Ed. Dialética. São Paulo. p. 14.

${ }^{6}$ PAULSEN, Leandro, Impostos Federais Estaduais e Municipais, 2012, Ed. , p. 36
} 
impositiva dividindo-a em espécies de renda quando, no final, se deve apurar o valor informado pela universalidade. Desta forma, para que a renda seja informada pelo critério da universalidade, os elementos integrados no processo de sua produção devem estar dispostos de forma tal que atendam a este critério. $\mathrm{Ou}$ seja, todos devem ser submetidos à tributação de forma absolutamente igual. Não há receita diferente de outra, como não há despesa diferente de outra. ${ }^{7}$

A observância do critério da universalidade permite averiguar a real capacidade econômica do contribuinte, pois todas as suas rendas são levadas em conta no momento da tributação. Isso garante a observância do art. 145 , parágrafo $1^{\circ}, \mathrm{CF}$, o qual preceitua que os impostos, sempre que possível terão caráter pessoal e serão graduados segundo a capacidade econômica do contribuinte, o que demonstra, nesse ponto, a harmonia da Constituição Federal.

Uma consequência da universalidade é a periodicidade do imposto de renda, pois esse critério só faz sentido se for considerado em certos lapsos temporais pré-determinados. Insta salientar que a estipulação desse período não é um critério do imposto de renda, pois não está previsto no art. 153 , parágrafo $2^{\circ}, \mathrm{I}, \mathrm{CF}$

A referida periodicidade do imposto de renda também como justificativa a progressividade, que será analisada em seguida.

Por último, só é possível averiguar um acréscimo patrimonial do contribuinte após a estipulação de um período-base, no qual serão averiguadas as mutações patrimoniais do mesmo.

\subsection{Progressividade}

A progressividade importa numa carga tributária maior em razão da maior base de cálculo do contribuinte, garantindo uma cobrança mais justa

\footnotetext{
${ }^{7}$ RENCK, Renato Romeu. Imposto de Renda da Pessoa Jurídica - Critérios constitucionais de apuração da base de cálculo. Porto Alegre: Liv. do Advogado, 2001, p. 161
} 
do imposto de renda ${ }^{8}$. A consequência prática desse critério é a aplicação de uma alíquota maior na base de cálculo.

A eficiência desse critério só será possível se for observado juntamente com os critérios da universalidade e generalidade, pois permite assim que todas as rendas do contribuinte sejam tributadas, permitindo que alíquota devida à verdadeira faixa de renda seja aplicável além do fato de sem esse último critério, seria admitido, no direito brasileiro, um critério de seletividade quanto às pessoas que pagariam o imposto de renda e o reteriam na fonte.

Observa-se assim, com a aplicação em conjunto desses três critérios, a observância do princípio da isonomia, pois todos os contribuintes que possuírem acréscimos patrimoniais equiparados serão tratados igualmente, além do princípio da pessoalidade, pois respeita a capacidade econômica do contribuinte.

Parte da doutrina defende que o princípio da progressividade é um refinamento do postulado da capacidade contributiva, não sendo então uma decorrência necessária desse ${ }^{9}$. Isso porque, de acordo com essa teoria, a capacidade contributiva exige a proporcionalidade e não a progressividade como critério de aferição da capacidade econômica do contribuinte.

Posto isso, essa corrente defende que a progressividade é utilizada como um instrumento social, visando a redistribuição de riquezas como uma justificativa para adoção das alíquotas diferenciadas. Esse critério é entendido então como uma política social da lei tributária, mostrando-se então como um meio de intervenção no domínio sócio- econômico, o que culminaria na finalidade extrafiscal do imposto de renda.

\footnotetext{
${ }^{8}$ OLIVEIRA, Ricardo Mariz de. Fundamentos do imposto de renda, Ed: Quartier Latin, São Paulo. p. 258

${ }^{9}$ LEÃO, Martha Toríbio. ; A (Des)Proporcionalidade da Progressividade do Imposto de Renda da Pessoa Física no Sistema Brasileiro. Direito Tributário Atual , v. 28, p. 188-205, 2013.
} 
Independentemente da justificativa para a adoção da progressividade do imposto de renda, entende-se, no presente trabalho, que o uso desse critério é mais aconselhável do que a aplicação da proporcionalidade.

A proporcionalidade pressupõe que, qualquer que seja a base de cálculo, a alíquota aplicável será a mesma, ocorrendo um tratamento igual entre os desiguais. Por vez, a progressividade importa na alteração da alíquota aplicável, conforme haja a modificação da base tributável.

Todo ano, a receita federal divulga uma tabela progressiva, na qual estão dispostas as alíquotas aplicáveis a cada faixa de renda do contribuinte, ou seja, a cada base de cálculo.

\begin{tabular}{|c|c|c|}
\hline Base de cálculo (R\$) & Alíquota $(\%)$ & $\begin{array}{c}\text { Parcela a deduzir do IRPF } \\
\mathbf{( R \mathbf { } )}\end{array}$ \\
\hline Até $22.499,13$ & - & $1.687,43$ \\
\hline $\begin{array}{c}\text { De } 22.499,14 \text { até } \\
33.477,72\end{array}$ & 7,5 & $4.198,26$ \\
\hline $\begin{array}{c}\text { De } 33.477,73 \text { até } \\
44.476,74\end{array}$ & 15 & $7.534,02$ \\
\hline $\begin{array}{c}\text { De } 44.476,75 \text { até } \\
55.373,55\end{array}$ & 22,5 & $10.302,70$ \\
\hline Acima de 55.373,55 & 27,5 & \\
\hline
\end{tabular}

A tabela mensal do imposto de renda a partir do mês de abril do ano calendário de 2015, divulgada pela Receita Federal, possui os seguintes índices. Insta salientar que essa tabela muitas vezes é usada para o cálculo do valor devido referente à retenção na fonte de imposto de renda. 


\begin{tabular}{|c|c|c|}
\hline Base de cálculo $(\mathbf{R} \$)$ & Alíquota $(\%)$ & Parcela a deduzir do IRPF (R\$) \\
\hline Até $1.903,98$ & - & - \\
\hline De $1.903,99$ até $2.826,65$ & 7,5 & 354,80 \\
\hline De 2.826,66 até $3.751,05$ & 15 & 636,13 \\
\hline De 3.751,06 até $4.664,68$ & 22,5 & 869,36 \\
\hline Acima de 4.664,68 & 27,5 & \\
\hline
\end{tabular}

A análise da tabela progressiva anual da receita federal nos mostra que a progressividade da alíquota do imposto de renda cobrado anualmente vai até o total de $27,5 \%$, o qual será calculado com base na renda anual acrescida ao patrimônio do contribuinte.

Uma comparação com países europeus nos mostra que a progressividade lá tem um índice muito maior que o nosso. $\mathrm{O}$ fato interessante disso é que, nesses países, a homogeneidade da população prevalece, razão pela qual esse as alíquotas deveriam ser mais reduzidas

Um exemplo disso é a Holanda, cujas alíquotas do imposto de renda de pessoa física variam de $38,55 \%$ a $60 \%$. A alíquota máxima brasileira consegue ser menor do que a mínima desse país, o qual é desenvolvido e cuja desigualdade da população é muito baixa.

Vale ressaltar que, quanto às pessoas jurídicas, na Alemanha, as alíquotas podem chegar até o montante de $50 \%$ no caso dos lucros não distribuídos aos sócios e, consequentemente, retidos na pessoa jurídica.

Apesar da maior arrecadação em consequência das altas alíquotas cobradas nesses países, deve-se atentar ao fato de que essas medidas podem ter efeitos contrários aos desejáveis.

Uma alta alíquota como a da Holanda importaria num aumento do valor devido ao fisco a título do imposto de renda. Consequentemente, o 
contribuinte poderia produzir muito ao longo do ano, mas, em razão da alta renda percebida por ele, o valor tributado seria demasiadamente elevado, inibindo-o de trabalhar em face de tal medida.

Posto isso, deve-se atentar muito às consequências negativas advindas de um aumento demasiado das alíquotas incidentes sobre a base de cálculo do imposto de renda, para impedir que essas se concretizem.

\subsection{Generalidade}

A generalidade também é um dos critérios abarcados pelo art. 153, parágrafo $2^{\circ}, \mathrm{I}, \mathrm{CF}$ e significa, em contraposição à seletividade, que todas as situações serão tratadas sobre uma norma geral, ou seja, serão aplicadas a todos os contribuintes do imposto de renda indistintamente. ${ }^{10}$

Nas palavras de Luiz Emygdio Franco da Rosa Jr.

\footnotetext{
"A generalidade significa que todos devem pagar o imposto de renda sem haver desigualdades fiscais, devendo, portanto, ser o mais amplo possível, desde que observadas as normas gerais do CTN e da legislação pertinente. A uniformidade significa que os tributos devem ser repartidos entre os cidadãos com critérios idênticos". 11
}

Pode-se dizer que uma consequência da generalidade é o fato do imposto de renda não ter caráter extrafiscal, pois seu objetivo seria a mera arrecadação, não intervindo no domínio socioeconômico do meio em que é cobrado.

Vale ressaltar que nem todos concordam com esse entendimento, pois, há quem entenda haver uma finalidade extrafiscal desse imposto, conforme prévia explicação no ponto referente à progressividade.

\footnotetext{
10 OLIVEIRA, Ricardo Mariz de. Fundamentos do Imposto de Renda. Ed. Quartier Latin. São Paulo p. 253.

${ }^{11}$ JR., Luiz Emygdio F. da Rosa. Manual de Direito Tributário. Ed. Renovar. São Paulo. p. 611
} 
Apesar dessas características da generalidade, não há um impedimento quanto à instituição de critérios diferenciados entre as pessoas jurídicas e as físicas.

Ricardo Mariz de Oliveira entende que:

"Por força da generalidade, qualquer aumento patrimonial deve ser tratado por igual com todos os demais, sem distinções derivadas de quaisquer critérios discriminatórios. Sejam os aumentos patrimoniais derivados do trabalho ou do capital, sejam do trabalho autônomo ou assalariado, ou sejam produzidos por atividades ilegais, isto é, de qualquer causa pessoal ou patrimonial eficiente, devem todos receber tratamento idêntico." 12

Resta nítido o fato de que, em decorrência do critério da generalidade, o imposto de renda não deve ser seletivo, pois, para esse imposto, o fator principal é o acréscimo patrimonial, de forma que dois patrimônios que tenham tido o mesmo aumento deverão supor igualmente a carga tributária decorrente desse fato.

Após a explicação dos três critérios referentes ao imposto de renda, podemos perceber que a Constituição Federal, ao instituí-los, visou uma maior tecnicidade na tributação dos contribuintes pelos acréscimos patrimoniais.

12 OLIVEIRA, Ricardo Mariz de. Fundamentos do Imposto de Renda. Ed. Quartier Latin. São Paulo p. 254. 


\section{Capítulo 3. A retenção na fonte do imposto de renda brasileiro}

Após a breve exposição do surgimento do imposto de renda no modelo inglês, alemão e no brasileiro além explicação dos critérios informadores do Imposto de Renda, passa-se agora a abordagem histórica da retenção na fonte, analisando-se, depois, o funcionamento desse instituto no modelo brasileiro.

\subsection{Histórico da retenção na fonte do imposto de renda na Inglaterra}

O imposto de renda inglês, cuja natureza era provisória, eis que instituído para financiar o período das denominadas guerras napoleônicas, teve a sua cobrança cessada com a assinatura do Tratado de Amiens, em 1802, o qual findou as hostilidades entre França e Reino Unido.

Entretanto, o Tratado só perdurou por um ano, pois, em 1803, a guerra contra a França foi retomada, sendo novamente cobrado o imposto de renda, mas com algumas modificações de suma importância.

Uma de grande relevância foi a instituição da retenção na fonte do imposto de renda junto à própria fonte produtora do rendimento. Essa nova modificação reduziu as problemáticas da averiguação da renda junto a cada contribuinte individual, diminuindo, em suntuosa monta, a evasão desse imposto. 


\subsection{Histórico da retenção na fonte do imposto de renda no Brasil}

Insta salientar que o imposto de renda, com essa denominação, foi instituído em 1922, mas foi objeto de uma grande alteração por meio da lei 4.783 de 1923.

Em 1934, o imposto de renda passou a ter caráter constitucional, sendo abordado no artigo $6^{\circ}$.

Em 1954, por meio da lei 2.354 , foi instituído pela primeira vez a retenção na fonte do imposto de renda. Esse instituto, no contexto brasileiro, visava simplificar a tributação das pessoas físicas assalariadas que recebiam rendimentos de apenas uma fonte pagadora. Essas pessoas, por sua vez, ficavam dispensadas de apresentar a declaração de rendimentos ao final do exercício fiscal.

Nesse primeiro momento, a retenção na fonte incidia sobre rendimentos do trabalho entre $\operatorname{Cr} \$ 4.167,00$ a $\mathrm{Cr} \$ 10.000,00$, não sendo aplicado a valores diversos. Ressalta-se que o instituto não estava sujeito à progressividade.

Havia previsão legal, em 1954, de que quem tivesse valores descontados na fonte do trabalho assalariado poderia deduzi-los do imposto a pagar, a partir da declaração de rendimentos de 1956.

Modificações legislativas futuras culminaram no aumento das hipóteses de aplicação da retenção na fonte do imposto de renda. Posteriormente, os valores pagos a maior e devolvidos no momento da restituição do imposto de renda apurado passaram a ser corrigidos monetariamente, afim de por fim a uma injustiça que se perpetuava, a qual era a devolução em valores nominais.

Pode-se perceber então que a retenção na fonte do imposto de renda brasileiro tinha como finalidade principal simplificar a arrecadação, já que passou a não ser mais necessário o fim do exercício fiscal para recolher os 
valores devidos. Outra finalidade era a de diminuir as evasões fiscais. Portanto as causas que levaram a instituição do referido instituto no sistema brasileiro em muito se assemelham as do modelo inglês, previamente explicitadas.

\subsection{Retenção na fonte do imposto de renda no modelo brasileiro}

Existem hipóteses em que o imposto de renda será devido na fonte no ordenamento jurídico brasileiro. Nesses casos, considera-se ocorrido o fato gerador quando houver o pagamento, entrega ou remessa após a aquisição da disponibilidade jurídica da renda ou do provento, na visão de Ricardo Mariz de Oliveira. ${ }^{13}$

Insta salientar que o artigo 43 do Código Tributário Nacional preceitua como fato gerador do imposto de renda:

\footnotetext{
“Art. 43. O imposto, de competência da União, sobre a renda e proventos de qualquer natureza tem como fato gerador a aquisição da disponibilidade econômica ou jurídica:

I - de renda, assim entendido o produto do capital, do trabalho ou da combinação de ambos;

II - de proventos de qualquer natureza, assim entendidos os acréscimos patrimoniais não compreendidos no inciso anterior.

$\S$ 1o A incidência do imposto independe da denominação da receita ou do rendimento, da localização, condição jurídica ou nacionalidade da fonte, da origem e da forma de percepção. (Incluído pela $\operatorname{Lcp~n}^{\circ}$ 104, de 10.1.2001)

$\S 20 \mathrm{Na}$ hipótese de receita ou de rendimento oriundos do exterior, a lei estabelecerá as condições e o momento em que se dará sua disponibilidade, para fins de incidência do imposto referido neste artigo. (Incluído pela Lcp $\mathrm{n}^{\circ} 104$, de 10.1.2001)."
}

Uma análise do artigo transcrito deixa claro que o fato gerador do imposto de renda é a aquisição da disponibilidade econômica ou jurídica da renda ou dos proventos de qualquer natureza. Posto isso, sobre a mera expectativa de ganho futuro ou em potencial, não haverá a incidência do imposto.

${ }^{13}$ OLIVEIRA, Ricardo Mariz de. Fundamentos do Imposto de Renda. Ed. Quartier Latin. São Paulo p. 253. 
Por vez, pode estar presente apenas a disponibilidade econômica ou jurídica, não sendo necessária a simultaneidade dessas.

Outro ponto a ser analisado é que a simples posse de capital alheio não configura disponibilidade econômica ou jurídica. Essa é uma hipótese de disponibilidade financeira apenas, pois o possuidor não pode dispor livremente desse valor. Pelo fato do art. 43 CTN não fazer qualquer menção a esse tipo, a hipótese narrada não configura fato gerador do imposto de renda, impedindo a sua cobrança.

O termo renda foi definido como o produto do capital, do trabalho ou da combinação de ambos. Entretanto a conceituação desse termo ainda gera muita polêmica, sendo objeto de diversas correntes doutrinárias.

$\mathrm{O}$ conceito de renda prevalecente no direito brasileiro defende que o que interessa não é o resultado da exploração da fonte produtora e sim o aumento de patrimônio ${ }^{14}$. Pode-se dizer então que o critério material da hipótese de incidência desse imposto consiste na aquisição de aumento patrimonial, o qual pode ser verificado balanço patrimonial de uma empresa dentro de um período-base, ou seja, a quantidade de entradas e saídas ou pela mutação patrimonial de uma pessoa física.

Rubens Gomes de Souza brilhantemente defende que:

"o fato gerador do imposto de renda será sempre, com efeito, o aparecimento de uma relação de propriedade ou de posse entre um rendimento e o contribuinte, seja este de fato ou de direito, isto é, quer esteja o contribuinte em relação pessoal com a matéria tributável, quer se trate simplesmente de um contribuinte por força de designação legal"15

O Supremo Tribunal Federal tem adotado esse posicionamento ao exercer o controle de constitucionalidade de leis ordinárias, nas quais os legisladores usavam o termo renda em hipóteses em que não ocorria o acréscimo patrimonial, conforme o julgado que segue abaixo:

\footnotetext{
${ }^{14}$ CANOTILHO, J. J. Gomes; MENDES, Gilmar F.; SARLET, Ingo W.; STRECK, Lenio L. (Coords.). Comentários à Constituição do Brasil. São Paulo:Saraiva/Almedina, 2013.

${ }^{15}$ SOUSA, Rubens Gomes de. O fato gerador do imposto de renda. In: Tributário. SP: Saraiva, 1950, p. 178 
"Constitucional. Tributário. Imposto de Renda. Conceito. Lei n. 4.506, de 30.11.64, art. 38; CF/46, art. 15, IV, CF/67, art. 22, IV; EC 1/69, art. 21, IV. CTN, art. 43. I - Rendas e proventos de qualquer natureza: o conceito implica reconhecer a existência de receita, lucro, proveito, ganho, acréscimo patrimonial que ocorrem mediante o ingresso ou auferimento de algo, a título oneroso. CF/46, art. 15, IV; CF/67, art. 22, IV; EC 1/69, art. 21, IV. CTN, art. 43. II Inconstitucionalidade do art. 38 da Lei n. 4.506/64, que institui adicional de $7 \%$ de imposto de renda sobre lucros distribuídos. III - RE conhecido e provido" (RE 117.887-6-SP, STF, Pleno, rel. Min. Carlos Velloso, j. em 11.02.93, DJU-I, 23.04.93, p. 6923).

Posto isso, o presente trabalho adotará o conceito de renda como a aquisição de um aumento patrimonial, alinhando-se à corrente majoritária da doutrina sobre $\mathrm{o}$ assunto.

A retenção na fonte no modelo brasileiro foi instituída pelo fisco como uma forma de arrecadação do imposto de renda, sendo então um tipo específico desse e não um novo tributo, pois restam conservadas as suas peculiaridades referentes aos respectivos fatos geradores.

O objetivo da retenção na fonte do imposto de renda é que haja a tributação sobre acréscimos patrimoniais isolados, isso é, sem levar em conta o período-base, aplicável às pessoas físicas, para averiguar o real acréscimo patrimonial do contribuinte, hipótese essa que configura o fato gerador desse imposto.

Outra característica marcante dessa nova forma de arrecadação foi que a fonte pagadora do provento ou da renda passou a ser o sujeito passivo no lugar do contribuinte.

O imposto de renda retido na fonte é devido quando a fonte cumpre a sua obrigação de pagamento, ou seja, quando, em razão de uma obrigação de direito privado, ela realiza um pagamento a quem lhe era devido. Ressalta-se aqui o fato de que o seu fato gerador é a remessa, pagamento, entre outros eventos que envolvam um devedor e um credor, que importem em um acréscimo patrimonial desse último. 
Para ser devido o imposto de renda retido na fonte é necessária a configuração de um dentro de cinco eventos possíveis, conforme preceitua parte da doutrina. ${ }^{16}$

A referida doutrina, ao alegar que existem cinco eventos ensejadores da retenção da fonte do imposto de renda, baseia-se no Decreto-lei $\mathrm{n}^{\circ}$ 5844/43, o qual estabelece, no art. 100, que "A retenção do imposto, de que tratam os art. 97 e 98, compete à fonte, quando pagar, creditar, empregar, remeter ou entregar o rendimento."

O referido Decreto-lei estabelece que o recolhimento do imposto será efetuado no prazo de 30 dias contados da data em que se tornou obrigatória a retenção pela fonte, ou pelo procurador residente ou domiciliado no estrangeiro.

O primeiro evento é o pagamento. Ressalta-se que se pressupõe que o destinatário do pagamento já tenha adquirido a disponibilidade jurídica do mesmo, sendo um direito adquirido seu.

$\mathrm{O}$ termo pagamento aqui deve ser entendido como a entrega de um objeto ou dinheiro, para extinguir uma obrigação de direito privado que o pagador esteja sujeito. Por vez, em decorrência do artigo 110 do código tributário nacional, o referido instituto deve ser compreendido como é no direito privado, sendo incabível a modificação da sua definição no direito tributário, de forma a alterar a sua natureza.

Não se deve confundir o pagamento com as hipóteses de antecipação ou até mesmo adiantamento, em que há a entrega do bem sem a existência de uma obrigação devida.

A mera antecipação do pagamento não constitui fato gerador do imposto de renda, sendo, consequentemente, incabível a sua retenção na fonte, pois a parte que o recebe ainda não adquiriu a disponibilidade

\footnotetext{
${ }^{16}$ OLIVEIRA, Ricardo Mariz de. Fundamentos do Imposto de Renda. Ed. Quartier Latin. São
} Paulo p. 500. 
jurídica da renda ou do provento que o pagamento importa, não cumprindo então o requisito do artigo 43 do código tributário nacional.

Posto isso, decorre o entendimento de que a mera antecipação do pagamento implica na aquisição da disponibilidade financeira do valor em questão, o que não é suficiente para retê-lo na fonte.

Um aspecto interessante a ser observado é que, se houver inadimplemento por parte do responsável pelo pagamento, não estará configurada a obrigação tributária, pois, como previamente explicado, o fato gerador da retenção na fonte do imposto de renda só restará configurado quando do cumprimento da referida obrigação.

Esse entendimento tem respaldo legal no artigo 116, inciso II do código tributário nacional, segundo o qual "salvo disposição de lei em contrário, considera-se ocorrido o fato gerador e existentes os seus efeitos: tratando-se de situação jurídica, desde o momento em que esteja definitivamente constituída, nos termos de direito aplicável." Sendo o pagamento um elemento da situação jurídica, a ausência desse importa na não ocorrência do fato gerador.

Devemos atentar à hipótese em que a fonte antecipa o pagamento em relação à data pactuada. Nesse caso já está configurada a obrigação, tendo sido pactuada livremente uma data limite para o seu cumprimento. Caso, por livre arbítrio, a parte decida pagar antes do tempo, haverá uma antecipação da ocorrência do fato gerador, devendo ocorrer a retenção na fonte.

Passa-se agora à análise do evento creditar, o qual também enseja a retenção na fonte do imposto de renda. Insta salientar que todos os eventos presentes no artigo 100 do Decreto-lei 5.844/43 importam numa disponibilização da renda ao credor, resultando no cumprimento de uma obrigação devida perante esse. De tal forma o beneficiário desses rendimentos adquire a disponibilidade jurídica, configurando o fato gerador do imposto de renda. 


\title{
O entendimento de que a disponibilização da renda ao beneficiário
} importa na aquisição da sua disponibilidade jurídica por esse tem respaldo na doutrina, conforme será visto.

José Luiz Bulhões Pedreira, ao adotar esse entendimento, alega que:

\begin{abstract}
"A renda pessoal resulta da repartição da renda social. Pressupõe, portanto, atos dos agentes da repartição. E como o ordenamento jurídico não admite a execução privada das obrigações, a aquisição da disponibilidade de renda pressupõe ato da fonte pagadora do rendimento (ou da autoridade judiciária, suprindo sua omissão) que torne o rendimento disponível para o beneficiário. Daí a noção, construída pela jurisprudência administrativa, de que ocorre disponibilidade jurídica quando a fonte pagadora coloca a renda à disposição do beneficiário. A partir desse momento a renda está disponível, porque o beneficiário, além de ser titular de direito a recebê-la, tem o poder de adquirir a disponibilidade econômica." ${ }^{17}$
\end{abstract}

\section{O jurista Gilberto Ulhôa Canto, por sua vez, preceitua que:}

“(...) De fato, ao dispor sobre a responsabilidade da fonte pagadora do rendimento, pela retenção do tributo, diz o vigente Regulamento do Imposto de Renda, aprovado pelo Decreto $n^{\circ} 58400$, de 10.5.1966 (cuja redação pouco difere da adotada nos textos anteriores):

Art. 309 - Compete à fonte reter o imposto de que trata o Título I deste Livro quando pagar, creditar, empregar, remeter ou entregar o rendimento.

A forma verbal utilizada pelo legislador não deixa qualquer dúvida quanto a só ser obrigatória a retenção do imposto pela fonte quando esta agir por uma das maneiras pelas quais a lei prevê a exteriorização do fato gerador, na espécie: pagar, creditar, empregar, remeter ou entregar o rendimento. Trata-se de forma verbal ativa, que pressupõe um 'facere' por parte da fonte, e que de maneira alguma se coaduna com a interpretação adotada pela instância ministerial, que equipara a palavra crédito, com o sentido de lançamento contábil a favor do titular da conta, à mesma palavra com o significado de direito ao recebimento de uma prestação em dinheiro ou a este redutível. A exigibilidade de um pagamento, tão logo ocorra o fato dele determinante, segundo a relação contratual que lhe dá origem - como o vencimento de prazo - independe de qualquer atuação da fonte. Ora, para fins de retenção do imposto, quis a lei que a obrigação respectiva só surgisse em razão de atividade específica da fonte pagadora, de ato positivo seu, qual seja: o creditar, o pagar, o empregar, o remeter ou o entregar o rendimento. Quisesse a lei que o fato gerador da obrigação tributária em causa surgisse com o só vencimento do prazo contratual, tê-lo-ia dito, sem dúvida, de forma clara, sem condicionar a ocorrência do fato gerador a um ato positivo, um 'facere' da fonte pagadora do rendimento, como a forma verbal utilizada demonstra. Portanto, é inviável a inteligência dada à palavra crédito para compreender tanto o registro contábil como o direito de haver prestação contratual, pois a lei fala em creditar e não em crédito; e, se o substantivo poderia ter o duplo sentido, o verbo não pode. Em segundo lugar, a decisão sob exame discrepa da jurisprudência do Conselho de Contribuintes e da extinta Divisão do Imposto de Renda.

17 PEDREIRA, José Luiz Bulhões. "Imposto de Renda- Pessoa Jurídica”. Adcoas-Justec, 1979, vol. I, p. 120. 
Também a doutrina não dá abrigo à tese final adotada, como se vê no lúcido comentário de Tito Rezende, que adiante se transcreve, no sentido de não caber a retenção do imposto sobre juros, por serem os mesmos devidos, mas tão-somente quando pagos.

'Em muitos casos' diz o saudoso fiscalista, 'entendeu o Conselho - e acertadamente ante os termos da lei - que não é exigível o imposto sobre os juros de debêntures simplesmente devidos pelas empresas, senão no momento em que forem pagos tais juros. No caso, entretanto, o fisco não está exigindo imposto sobre a totalidade dos juros devidos, mas tão-somente sobre a parte deles que confessadamente foi paga, conforme se vê do balanço anexo ao processo.

Finalmente, a tese adotada pela instância ministerial implica em privar de eficácia palavras usadas no texto legal, contrariando a regra básica da interpretação: 'Verba cum effectu sunt accipienda'. De fato, a decisão final prolatada no aludido processo (e em outros semelhantes, do interesse do mesmo contribuinte) faz com que quatro dos cinco fatos geradores previstos no transcrito art. 309 do Regulamento do Imposto de Renda, percam, por completo, qualquer efeito. Em realidade, ainda que fosse lexicamente possível - q-e não é - atribuir-se ao verbo creditar significado igual ao do vencimento da obrigação ou de surgimento do crédito pelo decurso do prazo contratual, ficariam vazios de conteúdo os demais verbos consignados no dispositivo legal em tela, quais sejam: pagar, remeter, empregar e entregar. Guardada a ordem cronológica em que tais fatos ocorrem, é de toda evidência que a ação decorrente de qualquer dos quatro verbos acima enumerados só terá lugar depois de vencida a dívida, ou seja, depois do decurso do prazo contratual. Assim, alçado o vencimento da dívida à categoria de fato gerador da obrigação tributária respectiva, jamais se dará a hipótese de qualquer dos atos pagar, remeter, empregar ou entregar o rendimento poder constituir exteriorização do fato gerador (como quer a lei) da obrigação tributária respectiva, porque o vencimento do débito lhes antecederá sempre." 18

Decorre dos trechos transcritos o entendimento de que o crédito o ato pelo qual uma pessoa salda uma dívida existente perante um terceiro, cumprindo a sua obrigação.

O termo crédito ainda gera muitas dúvidas, especialmente quanto à sua caracterização, pois em muito se assemelha ao pagamento. $\mathrm{O}$ entendimento do conceito foi amadurecido após ser objeto de diversos pareceres, ações judiciais e discussões.

Ricardo Mariz de Oliveira entende que:

Crédito, para o fim de determinação da retenção do IRF, embora também seja representado graficamente por um lançamento contábil em favor do beneficiário, deve, contudo necessariamente ser a

${ }^{18}$ CANTO, Gilberto Ulhôa. Estudos e Pareceres do Direito Tributário - Imposto de Renda. São Paulo: Revista dos Tribunais, 1975. p . 376 
contrapartida de um débito representativo de obrigação de direito privado, já existente para a fonte pagadora e já vencida. ${ }^{19}$

Há então um reconhecimento da dívida devida pela fonte, a qual faz o pagamento ao credor devido, posteriormente definido como beneficiário. Ressalta-se aqui o fato de que o valor pago já está vencido e isso que, basicamente, diferencia o crédito do pagamento, pois nesse não ocorreu o vencimento.

Insta salientar que, ao creditar o valor devido ao beneficiário, a fonte pode destacar desse montante o total do imposto retido na fonte que é devido. Após esse procedimento, apenas o valor líquido será creditado ao beneficiário, ou seja, valor do qual já foi abatido o devido ao fisco pela retenção na fonte.

Passa-se agora a análise dos três últimos eventos ensejadores da retenção da fonte do imposto de renda, conforme o dispositivo supracitado, os quais são: remessa, entrega e o emprego da renda.

A remessa de renda ocorre quando a fonte envia dinheiro, em geral para o exterior, ou seja, para outro país, em que o beneficiário se encontra.

A entrega de renda é um ato físico pelo qual a fonte transfere pessoalmente o montante devido ao beneficiário. Essa transferência também pode ser feita a alguém que tenha sido autorizado por ele a receber.

Por último, o emprego da renda ocorre quando, em decorrência de um pedido, instrução do beneficiário, a fonte utiliza o montante devido em algo que seja de seu interesse. Insta salientar que esse uso específico decorre de uma manifestação expressa do beneficiário.

Após a definição das expressões usadas no diploma legal, deve ser feita a seguinte constatação: todos esses atos representam um pagamento extintivo da obrigação, o qual enseja a ocorrência do fato gerador.

${ }^{19}$ OLIVEIRA, Ricardo Mariz de. Fundamentos do Imposto de Renda. Ed. Quartier Latin. São Paulo p. 512. 
Parte da doutrina defende que a tanto a remessa como a entrega e o emprego seriam modalidades de pagamento, razão pela qual as leis tributárias atuais os omitem, fazendo menção somente ao pagamento e/ou o crédito como fatos geradores da retenção na fonte do imposto de renda.

Quanto a esses três eventos, caso a fonte realize um adiantamento ao beneficiário, não terá que recolher o valor devido pela retenção na fonte, eis que ainda inexistente a disponibilidade jurídica da renda e questão além de não ser uma hipótese de pagamento, o que ensejaria o pagamento do imposto.

Obviamente o imposto de renda retido na fonte só passaria a ser devido quando houvesse a aquisição da disponibilidade jurídica da renda ou do provento.

Um ponto importante a ser analisado é que caso haja a retenção na fonte do imposto de renda sem o correspondente recolhimento à Fazenda Pública, ou seja, aos cofres públicos caracteriza crime tributário, conforme o art. $2^{\circ}$ da lei 8.137/90, o qual preceitua que:

Art. $2^{\circ}$ Constitui crime da mesma natureza: (Vide Lei $\mathrm{n}^{\circ}$ 9.964, de 10.4.2000)

I - fazer declaração falsa ou omitir declaração sobre rendas, bens ou fatos, ou empregar outra fraude, para eximir-se, total ou parcialmente, de pagamento de tributo;

II - deixar de recolher, no prazo legal, valor de tributo ou de contribuição social, descontado ou cobrado, na qualidade de sujeito passivo de obrigação e que deveria recolher aos cofres públicos;

III - exigir, pagar ou receber, para si ou para o contribuinte beneficiário, qualquer percentagem sobre a parcela dedutível ou deduzida de imposto ou de contribuição como incentivo fiscal;

IV - deixar de aplicar, ou aplicar em desacordo com o estatuído, incentivo fiscal ou parcelas de imposto liberadas por órgão ou entidade de desenvolvimento;

$\mathrm{V}$ - utilizar ou divulgar programa de processamento de dados que permita ao sujeito passivo da obrigação tributária possuir informação contábil diversa daquela que é, por lei, fornecida à Fazenda Pública.

Pena - detenção, de 6 (seis) meses a 2 (dois) anos, e multa.

Nessa situação fática, estará caracterizado o crime de apropriação indébita, eis que a fonte pagadora deixou de cumprir com a sua obrigação.

O julgado abaixo mostra que o Tribunal Regional Federal da $2^{\mathrm{a}}$ Região segue o mesmo entendimento. 
TRF-2 - APELAÇÃO CRIMINAL ACR 6152 RJ 2006.50.01.000110-2 (TRF-2)

Ementa: PENAL E PROCESSUAL PENAL - CRIME CONTRA A ORDEM TRIBUTÁRIA - NÃO REPASSE DOS VALORES DE IMPOSTO DE RENDA RETIDOS NA FONTE - ART. $2^{\circ}$, II , DA LEI No $8.137 / 90$ - PENA-BASE CONTINUIDADE DELITIVA - SUBSTITUIÇÃO DA PENA PRIVATIVA DE LIBERDADE - PENA DE MULTA - Devidamente comprovado o desconto do imposto de renda na fonte (IRRF) incidente sobre os rendimentos de trabalho assalariado pagos a terceiros, sem o devido repasse ao Fisco dos valores descontados, mostra-se correta a condenação pela prática do crime do art. $2^{\circ}$, II , da Lei $n^{\circ} 8137 / 90$, na medida em que o réu não desincumbiu de demonstrar inequivocamente que a empresa enfrentava graves e inarredáveis dificuldades financeiras. - Exasperação da pena-base, em considerando a culpabilidade do acusado, de formação universitária, de quem se espera conduta exemplar no cumprimento às leis e consequiente repulsa ao crime. - Aumento da pena de multa, que deve guardar a mesma proporcionalidade do aumento da pena-base. No entanto, não havendo elementos capazes de averiguar concretamente a situação econômica do réu, o quantum do dia-multa deve ser fixado no mínimo legal. - Majoração da pena em 1/2 em razão da continuidade delitiva (art. 71, do Código Penal ), pois o réu incorreu na conduta incriminada por cinco vezes. Manutenção da substituição da pena privativa de liberdade por restritiva de direitos, haja vista o preenchimento dos requisitos objetivos e subjetivos previstos no art. 44 , do Código Penal . - Provimento parcial do recurso ministerial e improvimento o do réu. 


\section{Capítulo 4. Inconstitucionalidade da retenção na fonte por violação dos princípios constitucionais}

No capítulo anterior foi analisado que o imposto de renda, com fulcro no art. 153, parágrafo $2^{\circ}, \mathrm{I}$, da Constituição Federal, será informado pelos critérios da generalidade, da universalidade e da progressividade, na forma da lei.

O dispositivo em tela deixa claro que o imposto de renda deverá obedecer a esses critérios, não dando a discricionariedade ao fisco de poder observá-los ou não.

Consequentemente, todos os institutos do imposto de renda deveriam obedecer à mesma regra, ou seja, também deveriam ser informados pelos critérios da generalidade, universalidade e progressividade, de acordo com o estipulado em lei.

Entretanto, o instituto da retenção na fonte do imposto de renda constantemente não observa esses critérios, conforme será analisado em seguida, sendo "cobrado" de forma a desrespeitar o disposto na Constituição.

A doutrina e a jurisprudência mantêm-se inerte há um tempo sobre o assunto, sendo poucas as vozes a abordá-lo, como é o caso do jurista Ricardo Mariz de Oliveira.

De acordo com Ricardo Mariz de oliveira, grande parte da doutrina entende que o legislador possui a discricionariedade de aplicar os critérios ou não, pois o dispositivo em tela alega que esses deverão informar o imposto de renda "na forma da lei”. ${ }^{20}$

Essa corrente doutrinária entende ainda que, por isso, não haveria um direito subjetivo dos contribuintes, derivado da Constituição, o qual os legitimaria a invocá-lo judicialmente, quando a legislação

${ }^{20}$ OLIVEIRA, Ricardo Mariz de. Fundamentos do Imposto de Renda. Ed. Quartier Latin. São Paulo p. 264. 
infraconstitucional não observar os referidos critérios, para que, por essa, não seja obrigado.

Para fins didáticos, cabe conceituar o que Caio Mário da Silva Pereira conceituou como direito subjetivo:

\begin{abstract}
"O direito subjetivo, traduzindo, desta sorte, um poder no seu titular, sugere de pronto a ideia de um dever a ser prestado por outra pessoa. Quem tem um poder de ação oponível a outem, seja este determinado, como nas relações de crédito, seja indeterminado, como nos direitos reais, participa obviamente de uma relação jurídica, que se constrói com um sentido de bilateralidade, suscetível de expressão na fórmula poder-dever: poder do titular do direito exigível de outrem; dever de alguém para com o titular do direito. O dever pode ser um de tipo variável: dar, tolerar ou abster-se; enquanto o direito será sempre o mesmo, isto é, o poder de exigir o cumprimento do dever." ${ }^{21}$
\end{abstract}

A referida norma constitucional, de acordo com essa corrente, teria então um caráter meramente programático na visão de alguns, eis que não podem ser invocáveis por qualquer contribuinte além de serem destinados ao legislador.

Entretanto, deve-se observar que a referida norma tem caráter mandatório, pois, por fazerem parte da Constituição Federal, deve ser considerada para a elaboração das leis assim como para a interpretação e aplicação das mesmas. Posto isso, entende-se que os três critérios citados são considerados direitos subjetivos dos contribuintes, podendo invoca-los, para garantir a sua aplicação.

Insta salientar que os três critérios dispostos no art. 153, parágrafo $2^{\circ}, \mathrm{I}, \mathrm{CF}$, devem ser considerados princípios, diferenciando-se então de uma norma constitucional comum.

Quanto à questão da violação dos princípios constitucionais pela legislação infraconstitucional assim como pelos entendimentos dos julgados dos tribunais, Celso Antonio Bandeira de Mello, afirma que:

\footnotetext{
${ }^{21}$ PEREIRA, Caio Mário da Silva. Instituições de direito civil. Vol. 1, 25 edição, Rio de Janeiro, p. 29
} 
"Violar um princípio é muito mais grave que transgredir uma norma. A desatenção ao princípio implica não apenas a um específico mandamento obrigatório mas a todo o sistema de comandos. É a mais grave forma de ilegalidade ou inconstitucionalidade, conforme o escalão do princípio atingido, porque representa insurgência contra todo o sistema, subversão de seus valores fundamentais, contumélia irremissível a seu arcabouço lógico e corrosão de sua estrutura mestra. Isto porque, com ofendê-lo, abatem-se as vigas que o sustêm e alui-se toda a estrutura neles esforçada." 22

Para maiores esclarecimentos e evitar maiores confusões, passa-se agora aos esclarecimentos dos princípios e das normas jurídicas.

\subsection{Normas jurídicas}

Normas, conforme Humberto Ávila, são os sentidos que se podem obter a partir da interpretação sistemática de textos normativos, não sendo apenas um texto ou o conjunto deles. ${ }^{23}$

O intérprete da lei, a partir dos dispositivos, constrói normas constitucionais, ou seja, por esse meio o intérprete os analisa, explicitando os seus reais significados de acordo com os seus fins. Pode-se dizer então que, com base na interpretação do texto da Constituição é que as normas são criadas.

As normas, por vez, podem ser qualificadas em princípios ou regras, fato que depende em muito do seu intérprete.

Os princípios são objetos dos mais diversos estudos doutrinários, possuem definições e qualificações diversas, as quais serão observadas na presente monografia, para um maior entendimento.

De acordo com Josef Esser, o critério diferenciador dos princípios em relação às regras é que aqueles possuem um fundamento normativo no momento da tomada de decisões, ou seja, estabelecem fundamentos no

\footnotetext{
${ }^{22}$ MELLO, Celso Antonio Bandeira de. Elementos de Direito Administrativo. 1. Ed., p. 230.

${ }^{23}$ ÁVILA, Humberto. Teoria dos princípios. $4^{\mathrm{a}}$ Ed., Malheiros editores, p. 22
} 
ordenamento jurídico vigente, para que um mandamento específico seja encontrado. ${ }^{24}$

Os princípios inegavelmente são normas de grande relevância para o ordenamento jurídico, pois estabelecem fundamentos para a interpretação e consequente aplicação do direito. ${ }^{25}$

Pode-se dizer que os princípios possuem um conteúdo axiológico nítido, sendo desnecessárias as regras para a sua concretização além de receberem o seu sentido graças a um método dialético de complementação e limitação, sendo detentores de fundamentos.

Por vez, as regras são uma espécie das normas jurídicas de alta objetividade, determinando que seja feito exatamente o que for ali preceituado. Na hipótese de coalisão entre as mesmas, uma solução cabível é a exceção a uma deles, de modo a dirimi-lo ou a declaração de invalidade de uma delas.

Ricardo Lodi Ribeiro faz a distinção entre princípios e regras na seguinte forma:

\begin{abstract}
"Os princípios são comandos de otimização, que se traduzem em enunciados genéricos posicionados na faixa intermediária, no que tange à abstração, entre os valores e as regras. Os primeiros, ideias abstratas, dotadas de grande placidez e amplitude, mas que guardam, porém um baixo grau de concretude. Embora não contidos necessariamente nos textos legais, os valores informam todo o ordenamento jurídico, como a justiça, a segurança jurídica, a liberdade e a igualdade. As regras, ao contrário, revelam um alto grau de concretude, atribuindo direitos e deveres, se subordinando aos valores e princípios."26
\end{abstract}

O referido doutrinador deixa claro que, de acordo com a sua percepção, as regras possuem um alto grau de objetividade e, por isso, insustentável que duas regras contraditórias sejam válidas no mesmo sistema jurídico.

\footnotetext{
24 ESSER, Josef. Grundsatz und Norm in der richterlichen Fortbildung des Privatrechts, 4. impressão, Tübingen, 1990, p. 51.

25 LARENZ, Karl. Richtiges Recht. München, Beck, 1979, pág. 26. LARENZ, Karl.Methodenlehre der Rechtswissenschaft. 6. ed. München, Beck, 1991. p.474.

${ }^{26}$ RIBEIRO, Ricardo Lodi. A Elisão Fiscal e a LC n. 104/01, RDDT, pp. 83-141.
} 
Os princípios podem possuir um alto grau de abstração, os quais demandam a sua observância por meio de regras. Outros possuem uma maior objetividade, podendo-se dizer que, em muito, se assemelham às regras.

Caso os princípios entrem em conflito, o que costuma ocorrer no plano concreto, pode-se utilizar a técnica da pondereção de interesses, segundo a qual um princípio se ajusta mais ao caso em questão, deixando-se de observar o outro, mas o que não implica em sua superioridade nem na revogação do outro.

Posto isso, incabível a alegação de que existem princípios absolutos, os quais deveriam ser sempre observados em detrimento de outros.

Humberto Ávila, autor que discorre brilhantemente sobre o tema, define da seguinte forma os princípios e as regras:

\footnotetext{
"Os princípios são normas imediatamente finalísticas. Estas estabelecem um estado ideal de coisas a ser buscado e, por isso, exigem a adoção de comportamentos cujos efeitos contribuam para a promoção gradual daquele fim. Por exemplo, o princípio da moralidade administrativa estabelece um estado de confiabilidade, honestidade, estabilidade e continuidade nas relações entre o poder público e o particular, para cuja promoção são necessários comportamentos sérios, motivados, leais e contínuos. Daí a definição proposta para os princípios: 'Os princípios são normas imediatamente finalísticas, primariamente prospectivas e com pretensão de complementaridade e de parcialidade, para cuja aplicação demandam uma avaliação da correlação entre o estado de coisas a ser promovido e os efeitos decorrentes da conduta havida como necessária à sua promoção'.

As regras são normas imediatamente descritivas de comportamento, na medida em que descrevem o comportamento obrigatório, permitido ou proibido. Nesse sentido, podem-se definir as regras da seguinte forma: 'As regras são normas imediatamente descritivas, primariamente retrospectivas e com pretensão de decidibilidade e abrangência, para cuja aplicação exigem a avaliação da correspondência, sempre centrada na finalidade que lhe dá suporte ou nos princípios que lhe são axiologicamente sobrejacentes, entre a construção conceitual da descrição normativa e a construção conceitual dos fatos'. Exatamente por isso, as regras possuem uma rigidez maior, na medida em que sua superação só é admissível se houver razões suficientemente fortes para tanto, quer na própria finalidade subjacente à regra, quer nos princípios superiores a ela. No caso das limitações ao poder de tributar, as regras exercem uma função muito importante, uma vez que a Constituição Brasileira se caracteriza, justamente, pela atribuição do poder de tributar por meio de regras de competência. Sendo regras, preexcluem a livre ponderação principiológica e exigem a demonstração de que o
} 
ente estatal se manteve, no exercício de sua competência, no seu âmbito material." ${ }^{27}$

A referida qualificação traz um ponto a ser observado. Ao atribuir esse alto grau de subjetividade aos princípios, o legislador, inegavelmente, deu margem ao aplicador da norma para a interpretação, concretizando o indesejável decisionismo e legitimando um conservadorismo decorrente da aplicação subjetiva dessas normas.

Uma forma de contornar essa situação seria se houvesse a indicação de critérios minimamente objetivos para a sua aplicação pelos destinatários das normas.

Apesar das consequências negativas decorrentes da subjetividade dos princípios, pode-se dizer que os mesmos visam estabelecer uma conexão entre todo o ordenamento jurídico vigente, eis que estabelecem valores fundamentais a serem observados, especialmente pelo legislador infraconstitucional e pelo Poder Judiciário ao julgar as causas levadas ao seu conhecimento. ${ }^{28}$

Posto isso, as leis infraconstitucionais devem estar em consonância com os princípios que as informam. Quanto a esse aspecto, vale ressaltar que existem leis em que os princípios não estão ali expressos, mas podem e devem ser dali deduzidos, de forma a garantir a sua observância.

Os princípios podem se referir e serem aplicados quanto a um objeto previsto pela Constituição Federal ou por lei infraconstitucional, não precisando abranger todo o ordenamento jurídico ou um subsistema desse. ${ }^{29}$ Um exemplo dessa hipótese é o art. 153, parágrafo $2^{\circ}, \mathrm{I}, \mathrm{CF}$, o qual prevê três princípios a serem observados pelo imposto de renda (generalidade, universalidade e progressividade), apesar de terem a denominação de critérios.

\footnotetext{
${ }^{27}$ ÁVILA, Humberto. Sistema Constitucional Brasileiro. São Paulo: Saraiva, 2004. p. 38.

${ }^{28}$ OLIVEIRA, Ricardo Mariz de. Fundamentos do Imposto de Renda, São Paulo, Ed. Quartier Latin, p. 234

${ }^{29}$ Ibid. p. 237.
} 
Pode-se afirmar então que, para uma norma ser considerada um princípio, independe a sua localização topográfica dentro da Constituição Federal ou de outra lei.

Quanto ao assunto, Marco Aurélio Greco, já se pronunciou alegando que "a identificação de um princípio traz em si a convicção de se estar perante algo mais relevante, importante, imutável que uma simples norma". Isso ressalta o entendimento previamente exposto.

Por vez, os princípios constitucionais tributários devem ser consideradas determinações a serem cumpridas, observadas nas ações positivas do legislador, conforme Marco Aurélio Greco. ${ }^{30}$

Apesar de toda a distinção entre princípios e regras previamente feita, um fato objetivo é que o art. 153, parágrafo $2^{\circ}, \mathrm{I}, \mathrm{CF}$ faz menção aos critérios da generalidade, universalidade e progressividade como informadores do imposto de renda, os quais, no presente trabalho, são entendidos como princípios. Inegável então que o referido artigo é no mínimo, uma norma constitucional.

Ao serem dispostos na Constituição Federal, os referidos princípios passam a ter uma superioridade jurídica sobre outros atos normativos, devendo então serem observados pelo legislador infraconstitucional.

O embasamento para tal alegação é o princípio da supremacia da constituição, decorrente do fato da nossa constituição ter sido elaborada pelo poder constituinte originário além de ser rígida. ${ }^{31}$

O princípio da supremacia da constituição tem como consequência a subordinação do conteúdo de toda a atividade normativa infraconstitucional à conformidade com os princípios e regras da Constituição Federal. Em razão disso, a inobservância dos preceitos constitucionais culmina no controle de constitucionalidade desses atos normativos.

\footnotetext{
${ }^{30}$ GRECO, Marco Aurélio. In: MACHADO, Hugo de Brito. Imunidade do Livro Eletrônico. Editora IOB, 1988, p. 145

${ }^{31}$ BARROSO, Luís Roberto. Interpretação e aplicação da Constituição. São Paulo, Ed. Saraiva. p. 150
} 
O controle de constitucionalidade pelo poder judiciário da norma em contradição com a Constituição Federal pode ter como consequência a declaração de sua não validade, deixando de ser aplicada no ordenamento jurídico vigente, nas hipóteses de controle concreto, ou ela não será aplicada ao caso concreto que envolva as partes, na hipótese de controle abstrato.

Feitas essas observações, deve se atentar ao fato de que a inobservância, pelo legislador infraconstitucional, dos princípios informadores do imposto de renda, está sujeita ao controle de constitucionalidade tanto difuso como concentrado. Isso importa na declaração de inconstitucionalidade dos atos normativos que não os observem, independentemente de serem entendidos como princípios ou meras regras.

\subsection{Inobservância, pela retenção na fonte do imposto de renda, dos princípios informadores da Constituição Federal}

Conforme exposição previamente feita, os três critérios informadores do imposto de renda, generalidade, uniformidade $\mathrm{e}$ progressividade, constantes do art. 153 , parágrafo $2^{\circ}, \mathrm{I}, \mathrm{CF}$ tem natureza de princípios, sendo mandatórios e, consequentemente, regendo a atividade do legislador além poderem ser invocados pelos destinatários das normas, eis que compõem o ordenamento jurídico vigente, configurando um direito subjetivo dos contribuintes.

Caso o legislador inconstitucionalmente não os observe, o contribuinte poderá se valer de algumas medidas judiciais como o controle de constitucionalidade das normas em descompasse com os princípios e o mandado de injunção para garantir a elaboração de normas observadores dos mesmos. 
Insta salientar que os princípios informadores do imposto de renda estabelecem um estado ideal a ser seguido, alcançado, o que demanda uma atuação do legislador, de forma a observá-los no momento da elaboração dos atos normativos, para que produzam, gradualmente, o fim a que se destinam. Isso demonstra que os referidos "critérios", na terminologia da norma constitucional, aproximam-se da definição de Humberto Ávila sobre princípios.

O termo "na forma da lei" disposto no final do art. 153, parágrafo $2^{\circ}, \mathrm{I}, \mathrm{CF}$, não tem o condão de conceder ao legislador a discricionariedade de observar ou não os princípios informadores do imposto de renda.

A redação do artigo tem lugar eis que os três princípios informadores tem caráter genérico, algo inerente aos princípios, conforme explicitado previamente, e, por isso, demandam, por meio de lei, uma maior objetividade, possibilitando uma regulação minuciosa dos mesmos.

Uma prova disso é a periodicidade da cobrança do imposto de renda. Como se sabe, o imposto de renda das pessoas físicas é cobrado dos contribuintes após um período-base de um ano. Isso permite a real verificação das mutações patrimoniais dos mesmos, influindo na alíquota a ser cobrada além de garantir a observância do princípio da universalidade. Tal fato só é possível em razão de uma lei infraconstitucional que estipula o respeito ao prazo anual para a cobrança desse tipo de imposto de renda.

Posta essa observação, passa-se a análise das consequências da aplicação dos três princípios informadores do imposto de renda em relação à retenção na fonte.

Primeiramente, conforme abordado no capítulo 2, a retenção na fonte do imposto de renda tem cinco eventos ensejadores da sua "aplicação", os quais são: pagar, creditar, empregar, remeter ou entregar o rendimento. 
Posto isso, uma nítida consequência da aplicação dos três princípios informadores é a incompatibilidade entre eles e toda incidência do imposto de renda sobre fatos isolados.

Em muitas hipóteses, o imposto de renda retido na fonte possui uma alíquota única, o que viola nitidamente o princípio da progressividade, eis que não há a progressão de alíquotas incidentes sobre as diferentes bases de cálculo. Nessas hipóteses, pode-se dizer que prevalece a ideia da proporcionalidade da alíquota, pois é a mesma independentemente do rendimento auferido.

Em outros casos, mesmo existindo uma tabela progressiva das alíquotas cobradas no imposto de renda retido na fonte, a referida progressividade deve ser considerada falsa, eis que aplicada a apenas a alguns fatores do acréscimo patrimonial do contribuinte e não sobre todos durante o período-base estipulado em lei. ${ }^{32}$

Quanto a esse aspecto, vale ressaltar que o fato gerador do imposto de renda é o acréscimo patrimonial, o qual é apurado dentro de um período base de um ano normalmente no caso das pessoas físicas.

Ao reter na fonte o imposto de renda em razão de um pagamento, por exemplo, o fisco desconsidera outros fatores negativos do acréscimo patrimonial que podem ser compensados com esse evento ensejador da retenção na fonte, ou seja, o IRRF pode ser cobrado mesmo que não tenha ocorrido acréscimo patrimonial algum do contribuinte.

Vale ressaltar que mesmo sendo de responsabilidade da fonte pagadora a retenção na fonte, o valor retido pode ser abatido do montante a ser repassado ao contribuinte, prejudicando-o.

Outra inconstitucionalidade do imposto de renda retido na fonte ocorre quanto à inobservância do princípio da generalidade.

\footnotetext{
32 OLIVEIRA, Ricardo Mariz de. Fundamentos do Imposto de Renda, São Paulo, Ed. Quartier Latin, p. 269.
} 
Segundo Ricardo Mariz de Oliveira, o princípio da generalidade importa que todas as situações serão tratadas sobre uma norma geral, ou seja, serão aplicadas a todos os contribuintes do imposto de renda indistintamente.

Por vez, ao serem cobradas alíquotas diversas em hipóteses diferentes no imposto de renda retido na fonte, chega-se a conclusão de que nem todas as situações são tratadas sobre uma norma geral comum, eis que há uma nítida distinção entre as espécies de rendas e proventos, culminando na inobservância do princípio da generalidade. ${ }^{33}$

O princípio da universalidade também é inobservado no IRRF. Vale ressaltar que, de acordo com esse doutrinador:

"O princípio da universalidade exige que se tribute todo o aumento patrimonial ocorrido no período previsto em lei, por inteiro e em conjunto, sem fracioná-lo e novamente sem distinguir as espécies de rendas e proventos, ajustando-se, assim, ao princípio da generalidade." ${ }^{\text {34 }}$

Como já explicado, o imposto de renda tem cinco eventos ensejadores da sua aplicação.

Uma vez ocorrido um desses eventos, será devida a retenção na fonte do imposto de renda pela fonte pagadora, podendo ser abatido essa valor do total a ser repassado ao contribuinte.

Entretanto, na maior parte das vezes, esse evento não corresponde a todo aumento patrimonial do contribuinte dentro de um período-base, eis que podem ter ocorrido outras hipóteses que não ensejam a retenção na fonte, mas que importam em um acréscimo patrimonial ou que compensem negativamente esses fatores positivos.

\footnotetext{
${ }^{33}$ OLIVEIRA, Ricardo Mariz de. Fundamentos do Imposto de Renda, São Paulo, Ed. Quartier Latin, p. 269.

${ }^{34}$ Ibid. p. 256.
} 
Há então o fracionamento do aumento patrimonial auferido pelo contribuinte ao se reter na fonte o imposto de renda, não correspondendo à sua realidade fiscal.

Portanto o princípio da universalidade não é observado pelo IRRF, pois nem todos os acréscimos patrimoniais são tributados dessa forma, ou seja, há um tratamento diferenciado entre certas rendas e proventos conforme prévia explicação, o que o torna inconstitucional quanto a esse aspecto.

Conclui-se então que o Imposto de Renda retido na fonte, por violar os três princípios informadores constantes do art. 153 , parágrafo $2^{\circ}, \mathrm{I}, \mathrm{CF}$, conforme prévia exposição, é inconstitucional, devendo então ser adaptado, ou seja, sofrer modificações na sua legislação, de forma a compatibilizar-se com esses, para que continue em vigor. 


\section{Conclusão}

O trabalho demonstrou o surgimento e desenvolvimento do imposto de renda, enfocando no modelo brasileiro. Analisou-se então os critérios informadores desse imposto e, posteriormente, a forma como o mesmo é retido na fonte, para, por último, adentrar no ponto central da presente monografia: a inconstitucionalidade da retenção da fonte do imposto de renda por inobservância dos princípios informadores.

Demonstrou-se que, apesar da Constituição Federal se valer dos termos critérios no art. 153, parágrafo $2^{\circ}$, I, os mesmos devem ser entendidos como princípios, eis que dotados de um alto grau de generalidade, estabelecendo um estado ideal a ser buscado, alcançado, o que os diferencia das simples regras, as quais são normas imediatamente descritivas de comportamento, possuindo uma alta objetividade.

Salienta-se que a expressão "nos termos da lei" disposta na referida norma constitucional não tem o condão de conceder ao legislador infraconstitucional a discricionariedade de observar ou não os princípios informadores do imposto de renda, mas visa muni-los de um maior grau de objetividade ao serem previstos e abordados em lei.

Resta configurado o caráter mandatório da referida norma constitucional, constituindo um direito subjetivo da parte que pode invocalo, para não se submeter à legislação infraconstitucional que não observe os princípios informadores do imposto de renda.

Por último, após a explicação de cada um dos princípios informadores do imposto de renda, o presente trabalho demonstra como o instituto da retenção da fonte não os observa, ou seja, viola-os.

Em razão dessa inobservância, conclui-se pela inconstitucionalidade do instituto da retenção na fonte do imposto de renda 
no modelo brasileiro, devendo ser adaptado, para que possa continuar em vigor. 


\section{Referências Bibliográficas}

ÁVILA, Humberto. Sistema Constitucional Brasileiro. São Paulo: Saraiva, 2004. p. 38.

ÁVILA, Humberto. Teoria dos princípios. $4^{\mathrm{a}}$ Ed., Malheiros editores.

BARROSO, Luís Roberto. Interpretação e aplicação da Constituição. São Paulo, Ed. Saraiva.

CANOTILHO, J. J. Gomes; MENDES, Gilmar F.; SARLET, Ingo W.; STRECK, Lenio L. (Coords.). Comentários à Constituição do Brasil. São Paulo:Saraiva/Almedina, 2013.

CANTO, Gilberto Ulhôa. Estudos e Pareceres do Direito Tributário Imposto de Renda. São Paulo: Revista dos Tribunais, 1975.

COSTA, Alcides Jorge da Costa. Imposto de Renda, alterações fundamentais. Ed. Dialética. São Paulo.

EMYGDIO, F. da Rosa Jr., Luiz, Manual de Direito Tributário, $2^{\mathrm{a}}$ Ed., Editora Renovar.

ESSER, Josef. Grundsatz und Norm in der richterlichen Fortbildung des Privatrechts, 4. impressão, Tübingen, 1990.

GAMMIE, Malcon. The origins of fiscal transparency in uk income tax. In: Tiley, John. Studies in the history of tax law. Volume 4. Oxford and Portland, Oregon: Hart Publishing, 2010.

GRECO, Marco Aurélio. In: MACHADO, Hugo de Brito. Imunidade do Livro Eletrônico. Editora IOB, 1988.

JR., Luiz Emygdio F. da Rosa. Manual de Direito Tributário. Ed. Renovar. São Paulo.

LARENZ, Karl. Richtiges Recht. München, Beck, 1979, pág. 26. LARENZ, Karl.Methodenlehre der Rechtswissenschaft. 6. ed. München, Beck, 1991, 
LEÃO, Martha Toríbio. ; A (Des)Proporcionalidade da Progressividade do Imposto de Renda da Pessoa Física no Sistema Brasileiro. Direito Tributário Atual, v. 28, 2013.

MELLO, Celso Antonio Bandeira de. Elementos de Direito Administrativo. 1. Ed.

OLIVEIRA, Ricardo Mariz de. Fundamentos do imposto de renda, Ed: Quartier Latin, São Paulo.

PAULSEN, Leandro, Impostos Federais Estaduais e Municipais, 2012.

PEDREIRA, José Luiz Bulhões. "Imposto de Renda- Pessoa Jurídica". Adcoas-Justec, 1979, vol. I,

PEREIRA, Caio Mário da Silva. Instituições de direito civil. Vol. 1, 25 edição, Rio de Janeiro.

RENCK, Renato Romeu. Imposto de Renda da Pessoa Jurídica - Critérios constitucionais de apuração da base de cálculo. Porto Alegre: Liv. do Advogado, 2001.

RIBEIRO, Ricardo Lodi. A Elisão Fiscal e a LC n. 104/01, RDDT.

Richtiges Recht, p.26, e Methodenlehre der Rechtswissenschaft, $6^{a}$ ed.

SOUSA, Rubens Gomes de. O fato gerador do imposto de renda. In:

Estudos de Direito Tributário. SP: Saraiva, 1950. 